should not see the use of such expteriments in the natural. To one who does undersitand their imme. tance, the wonder is that such ari opinion slatihave any weight in such a matter. The standard the early days of Bache is still the standard of a coast-survey work of to-day. Let us hope that ignorant criticism will have power to lower or it pair the efficiency of a department of whose scientit record the country may well be proud.

While criticising the article of the Evening post, so far as it relates to the coast-survey, let me express my complete agreement with its condemnation of the 'political scientist.' It is time that the system thus attacked should be abandoned, and that indiscriminate scientific assistance, given by the heads of bureaus to institutions and individuals, and never contemplated or sanctioned by congress, should be discontinued. It has brought nothing but discredit upon the official science of the country. Let the most liberal appropriations be made for the work of our scientific bureaus, but let the requisitions be so complete and detailed as to invite a fair and open criticism.

Cambridge, Mass, , Sept. 9.

Arexander Agassiz.

\section{THE THEORY OF VOLCANOES.}

This work is a brief statement of the most general facts relating to volcanoes, with the citation of many examples of volcanoes of various classes, and their subordinate phenomena, by way of illustration. It is evidently intended for the most intelligent class of general readers, though valuable also to the specialist.

In the first chapter, Mr. Vélain describes the phenomena attending a volcanic eruption of the normal type, and with great propriety treats such an occurrence as a manifestation of the energy of the elastic vapors contained in the erupting materials, - a fundamental fact which should always be impressed as forcibly as possible upon the general reader. He also describes the various forms given to the lavas, the modes of accumulation of volcanic piles, the formation of cinder-cones, and the many forms of craters. He gives descriptions of some of the more remarkable eruptions of which records have been preserved, and these are chosen so as to illustrate the typical cases of the several classes of volcanoes. In this chapter may be found much information about volcanoes not described in English treatises on this subject, such as those of Reunion and the Island of St. Paul.

The second chapter, on the gaseous emanations, is, to the American student, probably the

Les volcans, ce qu'ils sont et ce qu'ils nous apprennent. Par M. Ch. Vélain, docteur des sciences, maître de conférences à la Sorbonne. Paris, Gauthier-Villars, $1884.8^{\circ}$. most instructive ove in the book. The investigations of Charles Saint-Claire Deville, of Scacchi, of Fouqué and Lery, are set forth in considerable detail, and well summarized. These are of great importance, and have, no doubt, received less attention from writers in the English language than they are entitled to. It may be remarked, however, that much more extended observations upon this class of phenomena are needed than those upon which the conclusions of Deville and Fouqué are lounded. The pre-eminence of those investigators is a high warrant for the validity of their conclusions; but the experienced vulcanologist will perhaps feel that they are even more systematic and beautiful than he is accustomed to find volcanic phenomena to be, and he would like to see them tested by the widest possible rerification. The whole chapter is admirable reading, and excellently arrarged by $\mathrm{Mr}$. Vélain.

The third chapter desc ibes the lavas themselves, their methods of now, and the forms they assume at solidification. Very little effort is made to describe the micro-characters of the lava, and this was probably judicions on the author's part; for these characters cannot be briefly summarized, and any attempt to do so would have exceeded the scope of his work.

The fourth chapter treats of the geographic distribution of volcanoes. The main fict he seeks to establish is, that volcanoes are, with the rarest exceptions, situated near the sesi, or within it. At considerable length, and with reference to this generalization, he passes in review all the lines of active vents in the world. As a mere statement of facts, apart from any conclusions, his summary, though not free from errors, is a valuable one on many accounts : considered with reference to his generalizations, his treatment of the subject is open to grave criticism. One of the most important and comprehensive propositions he insists upon, is the linear arrangement of volcanoes. This idea has certainly a large amount of truth in it, but it has been enormously overloaded and overworked by writers of general treatises. The occurrence of half a dozen to a dozen small cones upon a single line of fracture twenty-five to a hundred kilometers in length, is very frequent in districts where the volcanic action has been diffuse. But a linear arrangement on a grand scale is another matter. The strongest case of it which can be cited is in South America, where many volcanoes are scattered in a most irregular array along the Andes; but no evidence has yet been brought to light, that any six, or even any three, of them have been built 
up over the same line of fracture. Viewed in their totality, they occupy a belt of country which is very long (over four thousand miles), and relatively narrow. Any one can judge for himself how far this arrangement is linear. Much the same may be said of the whole circuit of the North Pacific. In this volcanic girdle, there are many/distinct volcanic areas, and more or less elongated belts ; but the intervals between them are wide, and no inter-dependence has hitherto been shown to exist. Of course a line can be drawn through them all if it be crooked enough, and makes no note of the enormous gaps and echelons.

The generalization that volcanoes are near the sea, or in it, has also been overstrained. How far from the sea may a volcano stand, and still be said, to be near it? If we say ten' miles, then very few land-volcanoes are near the sea. If we say two hundred and fifty miles, then the statement holds good, but is shorn of a large part of its meaning. The reader must judge for himself whether a point a hundred and twenty miles or more from the sea is 'near' it; and the great volcanoes of North and South America are, on an average, about that distance from the ocean. Even in this qualified sense, the statement ceases to be true the mornent we recur to those volcanoes which were artive in middle and late tertiary time; for many of them in our own country were five hundsed to a thousand miles away from any body of water, and those of central France and Germany were almost as far from the ocean as the configuration of Europe would permit.

'The last chapter of Mr. Vélain's book, and the briefest of all, treats of the causes of volcanic action. In common with many others, he regards as the most acceptable view that lavas are squeezed out of a melted nucleus through a rocky crust by the contraction of the earth's interior by secular cooling. C. E. Dutron.

\section{BOLTON'S CATALOGUE OF SCIENTIFIC SERIALS.}

Ir can hardly be true, that the series of scientific publications, whether in the form of independent journals, or as publications of societies, can be found more complete in American libraries than in European; but it certainly has fallen to the new world to give to the old the best lists of such periodicals extant. Scudder's ' Catalogue of scientific serials,' published

A catalogue of scientific and technical periodicals (1665-1882), together with chronological tables, and a library check-list. By H. C. BoutoN. Washington, Smithson. inst., 1885. $8^{\circ}$. inside9, was almost the first attempt to embears in one volume the bibliography of publishins of this class; and the present volume, when brings the literature down to the close to the year 1882 , has improved in many reflects upon its predecessor. Especially is this the case in the fulness of the titles. The diference between these two publications is principally in that Scudder's catalogue was mainly restricted to pure science, while Bolton's extends to nearly all the fields of applied science, excepting medicine; but, on the other hand, with few exceptions, it does not include serials published by learned societies. The pains taken by Dr. Bolton is evident on every page of the catalogue, and it will long remain a most important auxiliary to every scientific library.

Besides yarious forms of index which add markedly to its value, especially the library check-list, enabling one to find at a glance where in America a given series may be found, we desire to call special attention to the chronological tables which follow directly the main list. In this, Bolton has followed a suggestion made many years since by Dana, but never hitherto carried into effect: it indicates the exact year for which each volume of certain long series of publications was issued; and it is an interesting study to see with what ingenuity the various changes undergone by such publications as the Edinburgh philosophical magazine for instance, with its various splits and absorptions, have been tabulated. In this list are included about five hundred of the most important journals; and it will save a vast amount of labor on the part of many a writer, who, with an eye to 'priority,' will wish to know in what year a certain volume of a given publication was issued.

The only criticism, which, it appears to us, can be made to the work, is on a matter which deals purely with typography. The type is much larger than is requisite or convenient for such a purpose, expanding the volume to nearly eight hundred pages : had it included, as we certainly wish it had, all publications of societies, its extent must have been doubled, and its bulk altogether unfortunate. This fault is especially seen in the chronological tables, which should have been compressed to nearly one-half their present space. It is one of the prime qualities of a good index, that it should be as compact as possible; and these tables, sharing as they do the nature of an index, ought thus to have been compressed. These, however, are faults only of style : concerning the body of the work, its method 